\title{
A Novel Bruton's Tyrosine Kinase Mutation in Russian Patient with X-Linked Agammaglobulinemia
}

\author{
S. Deryabina', I. Tuzankina', ${ }^{1,2}$, E. Vlasova ${ }^{2}$, A. Pavlova ${ }^{3}$, M. Bolkov ${ }^{1}$ \\ ${ }^{1}$ Institute of Immunology and Physiology UB RAS, Ural Federal University, Yekaterinburg, Russia \\ ${ }^{2}$ Regional Clinical Children Hospital No.1, Yekaterinburg, Russia \\ ${ }^{3}$ D. Rogachev National Research Center of Pediatric Hematology, Oncology and Immunology, Moscow, Russia \\ Email: ssderyabina@gmail.com, ituzan@yandex.ru, evvlasova@mail.ru, anashteyn@gmail.ru, antanariva@gmail.com
}

How to cite this paper: Deryabina, S., Tuzankina, I., Vlasova, E., Pavlova, A. and Bolkov, M. (2017) A Novel Bruton's Tyrosine Kinase Mutation in Russian Patient with X-Linked Agammaglobulinemia. Case Reports in Clinical Medicine, 6, 241-249. https://doi.org/10.4236/crcm.2017.610027

Received: July 25, 2017

Accepted: September 28, 2017

Published: October 1, 2017

Copyright $\odot 2017$ by authors and Scientific Research Publishing Inc. This work is licensed under the Creative Commons Attribution International License (CC BY 4.0).

http://creativecommons.org/licenses/by/4.0/

\begin{abstract}
$\mathrm{X}$-Linked Agammaglobulinemia (XLA) is the major primary immunodeficiency in which the body is unable to produce the antibodies responsible for the defense against bacteria and viruses. The patient (a 6-month-old boy) was born at term to non-consanguineous parents. Both parents and older sister are clinically healthy. At 3,5 months of age he presented acute viral infection with glue ear. At 4 month-serous meningitis, at 5 month-laryngotracheitis and serous meningitis. The levels of immunoglobulins were decreased for Ig A and IgG isotypes. The virtual lack of $\mathrm{CD}^{19+} \mathrm{B}$-lymphocytes was defined. Additionally there was found a complete absence of KREC (kappa-deleting recombination excision circle) in dried blood spot. The molecular diagnostics of coding region of the BTK gene was performed. DNA sequencing analysis of patient showed a 13-bp deletion in exon 2 (c.64_76delCCTCTAAACTTCA), leading to occurrence of frameshift and premature termination codon (p.Pro22fsTer28). This mutation was not described earlier. The mother and the sister of proband showed heterozygosity at the same position. Prenatal diagnostic testing has become available to this family for next pregnancy.
\end{abstract}

\section{Keywords}

X-Linked Agammaglobulinemia, Primary Immunodeficiency, BTK-Gene

\section{Background}

BTK is an enzyme that is encoded by the BTK gene, a member of Tec family tyrosine-protein kinases. BTK gene lies on the long arm of the X chromosome (Xq21.3 - Xq22) and its genetic defect results in disruption of B-lymphocytes 
maturation. Deficiency of B-cells is major sign of primary humoral immunodeficiency disorder-X-linked agammaglobulinemia (XLA), characterized predominatingly to recurrent viral and bacterial infections.

More than 500 mutations have been identified in BTK involving single base-pair (bp) substitutions, splice defects, small deletions and insertions [1]. In wide cohort studies it was proven, that various types of mutations in BTK gene don't have any relations to region of inhabitation [1], but much severe mutation was comparable with higher degrees in impairment of humoral characteristics [2], earlier onset of disease and severe infections [3]. However, prediction of clinical manifestations in case of particular gene abnormality still remains difficult, since a genotype-phenotype correlation is not tend to uncover in data.

In represented case in patient with XLA novel BTK-mutation and certain phenotype features was revealed.

\section{Materials and Methods}

Phenotyping of lymphocytes was carried out by flow cytometry on a flow cytometer FC-500 (Beckman Coulter, USA) with using the CXP-Analysis software (Beckman Coulter, USA). The gather of blood samples, sample preparation and tuning of a flow cytometer was performed according to the recommendations of a standardized technology for studying the subpopulation composition of peripheral blood lymphocytes [4].

Extraction of DNA from dry blood spots for real-time quantitative PCR was performed using a modified protocol for the commercial DNA-sorb-B kit (Amplisens, Russia).

Quantitative determination of TREC (T-cell receptor excision circle) and KREC (Kappa-deleting recombination excision circle) as markers of naive $\mathrm{T}$ and B cells was carried out using a multiplex kit "T \& B", created on the Institute of Chemical Biology and Fundamental Medicine of the Siberian Branch of the Russian Academy of Sciences (Novosibirsk) and Novosibirsk State Research University (Novosibirsk) and the Children's City Clinical Hospital No. 9 named by G. N. Speransky (Moscow) [5]. A multiplex PCR was performed on the CFX96 (“Bio-Rad", USA).

After informed consent had been obtained, genomic DNA was isolated from patient, family members and control healthy individual using a conventional MagNa Pure LC DNA Isolation Kit and DNA I Blood Cells High Performance protocol for automatically station MagNa Pure LC 2.0 (Roche, USA). All BTK gene exons and the intron-exon junctions were amplified by PCR using a set of primers developed by colleagues from laboratory of molecular biology in the $\mathrm{D}$. Rogachev National Research Center of Pediatric Hematology, Oncology and Immunology (Moscow) and synthesed by "Eurogene" (Moscow) (Table 1). In brief, $5.0 \mu \mathrm{l}$ of gDNA (20 - $100 \mathrm{ng}$ ) was amplified in $25 \mu \mathrm{l}$ containing: $1.0 \mu \mathrm{l} 20$ $\mathrm{pM} / \mu \mathrm{l}$ of primer mix, $25 \mu \mathrm{M}$ of each of dNTP, $2.5 \mu \mathrm{l}$ of buffer, and $1.0 \mu \mathrm{l}$ of Taq 
Table 1. Oligonucleotide sequences of primers for BTK gene.

\begin{tabular}{|c|c|c|}
\hline $\begin{array}{c}\text { Exon, Primer } \\
\text { (F-forvard, } \mathrm{R}-\text { revers })\end{array}$ & $\begin{array}{l}\text { Oligonucleotide sequences, } \\
\qquad\left(5^{\prime}-3^{\prime}\right)\end{array}$ & $\begin{array}{c}\text { Size of } \\
\text { PCR-product, b.p. }\end{array}$ \\
\hline $1 \mathrm{~F}$ & GCTCAGACTGTCCTTCCTCTC & \multirow{2}{*}{164} \\
\hline $1 \mathrm{R}$ & TGCCCAGCCCCTGCCATACC & \\
\hline $2 \mathrm{~F}$ & CACATTTTTGTTCCATTTGAAACTAG & \multirow{2}{*}{377} \\
\hline $2 \mathrm{R}$ & СТАСТССССТССТССТАССААС & \\
\hline $3 \mathrm{~F}$ & GCTTAATCССТCTTAАТCTTTCTCC & \multirow{2}{*}{188} \\
\hline $3 \mathrm{R}$ & TCTGCTGTTCCCCATCTCAGAC & \\
\hline $4 \mathrm{~F}$ & AAGAGCAATGCATCAACCAATAACC & \multirow{2}{*}{167} \\
\hline $4 \mathrm{R}$ & CTAATTGTGTTACAGGGGCCTTTC & \\
\hline $5 \mathrm{~F}$ & CCTTCAGATAGTTCACATAACCTGAAC & \multirow{2}{*}{398} \\
\hline $5 \mathrm{R}$ & СТАТССАТTTTTTТСТTСТTТTСТСТСТАС & \\
\hline $6 \mathrm{~F}$ & CAAAGAGGAAAACATGCAAATG & \multirow{2}{*}{306} \\
\hline $6 \mathrm{R}$ & CCAAAGTGTACAACCTTATGCTATG & \\
\hline $7 \mathrm{~F}$ & GCATTCCATATCATCACTGGCTTC & \multirow{2}{*}{132} \\
\hline $7 \mathrm{R}$ & CAGTGGCAGCACCCAGTTTCC & \\
\hline $8 \mathrm{~F}$ & АСССТССТАССТТТТСТССТААС & \multirow{2}{*}{319} \\
\hline $8 \mathrm{R}$ & GTCTCTGATGAGGATGCTGATCAC & \\
\hline $9 \mathrm{~F}$ & GGGAGGTGCATGATACATATACC & \multirow{2}{*}{225} \\
\hline $9 \mathrm{R}$ & CTCCTGGAAGATTGTGGACTGAC & \\
\hline $10 \mathrm{~F}$ & САCTCAAGCAGCACTCTCССТTC & \multirow{2}{*}{198} \\
\hline $10 \mathrm{R}$ & CAGACGATGGCAGCTTTGACAC & \\
\hline $11 \mathrm{~F}$ & САССАСТTССТССТАСAGACAGC & \multirow{2}{*}{148} \\
\hline $11 \mathrm{R}$ & CAGGGCCTTGGAATAGTAGCACTC & \\
\hline $12 \mathrm{~F}$ & CCCAAGTTACTGACTAAGCATCCAC & \multirow{2}{*}{186} \\
\hline $12 \mathrm{R}$ & CTTCTCAGTTGCCCCTGGTACTC & \\
\hline $13 \mathrm{~F}$ & CCTACACCACACCAACAGCATGACC & \multirow{2}{*}{158} \\
\hline $13 \mathrm{R}$ & CAACTGGCCAGTCCACCCTACCC & \\
\hline $14 \mathrm{~F}$ & GACCCCAAAGAATCACACCAAGAC & \multirow{2}{*}{234} \\
\hline $14 \mathrm{R}$ & GAGAGTTGAGTTTGGGCTATAACTCAC & \\
\hline $15 \mathrm{~F}$ & GTGACСССTTATCTGATGCTCTAC & \multirow{2}{*}{412} \\
\hline $15 \mathrm{R}$ & CCCTCAACCATGTATGATATATCTTC & \\
\hline $16 \mathrm{~F}$ & GAGTCTCACTGGTCTCTGTTTGCAC & \multirow{2}{*}{179} \\
\hline $16 \mathrm{R}$ & GAGGATTAAAACTGTAACACCTACC & \\
\hline $17 \mathrm{~F}$ & GCAACAAGTCCTGAATCCСTTGC & \multirow{2}{*}{199} \\
\hline $17 \mathrm{R}$ & CCATTGCATTTCTTATCCTTTGAGCTG & \\
\hline $18 \mathrm{~F}$ & GGAAGACTAGGACCCCTGCTATCCA & \multirow{2}{*}{285} \\
\hline $18 \mathrm{R}$ & CAGCTAAATGGGCAAGTAGATTCAAGG & \\
\hline
\end{tabular}

DNA Polymerase. The following program was used for all exons amplifications: pre-heating at $94^{\circ} \mathrm{C}$ during $5 \mathrm{~min}$ and then 5 cycles at $94^{\circ} \mathrm{C}$ for $20 \mathrm{~s}, 65^{\circ} \mathrm{C}$ for 20 $\mathrm{s}$ and $72^{\circ} \mathrm{C}$ for $40 \mathrm{~s}$, then $25 \mathrm{cycles}$ at $94^{\circ} \mathrm{C}$ for $20 \mathrm{~s}, 60^{\circ} \mathrm{C}$ for $20 \mathrm{~s}$ and $72^{\circ} \mathrm{C}$ for 40 s, with $10 \mathrm{~min}$ final extension at $72^{\circ} \mathrm{C}$ and storing at $4^{\circ} \mathrm{C}$ on thermosycler DNA EngineTM Dyad (Bio Rad, USA). The PCR fragments were analyzed and aligned 
using the Variant Reporter 2.0 and BioEdit softwares to detect mutations in the coding sequences and exon/intron junctions. The annotations and numbering of amino acids and nucleotides were done referring to the BTK gene sequence ENST00000308731 (NM_000061 and NP_000052). The identification of the mutations was carried out in accordance with the recommendations of J. den Dunnen [6].

Sequencing of the $B T K$ coding regions revealed a deletion c.64_76del13 (delCCTCTAAACTTCA) that resulted in to frameschift and premature termination codon (Figure 1). To our knowledge, this is the first report of the mutation c.64_76del13 at exon 2 of BTK-gene in the literature.

\section{Case Report}

Proband-child from the second pregnancy of 31-year old woman. The family is being social-well. Family socio-demographic characteristics, including age, education, origin, residence and employment status, as well as health-related factors are shown in Table 2.

A boy was born in time with a caesarian section with satisfactory mass and long at birth ( $\mathrm{m}-3390 \mathrm{~g}, 1-53 \mathrm{sm})$, was attached to the breast in 2 hours. BCG-M was instilled in a maternity hospital; against hepatitis of B. Mother and newborn were discharged from hospital on 5th twenty-four hours. In age of 1 month he was revaccinated against hepatitis of $B$.

Table 2. Sociodemographic and clinical characteristics of family P.

\begin{tabular}{|c|c|c|c|c|}
\hline \multicolumn{5}{|c|}{ Sociodemographic characteristics } \\
\hline & Father & Mother & Daughter & Son (proband) \\
\hline Age (years) & 32 & 31 & 8 & 0.5 \\
\hline Education Level & $\begin{array}{l}\text { secondary } \\
\text { vocational } \\
\text { education }\end{array}$ & $\begin{array}{c}\text { higher } \\
\text { education }\end{array}$ & - & - \\
\hline Residence & \multicolumn{4}{|c|}{ rural } \\
\hline Family income & \multicolumn{4}{|c|}{ middle } \\
\hline Social status & worker & housewife & schoolgirl & infant \\
\hline \multicolumn{5}{|c|}{ Clinical characteristics } \\
\hline $\begin{array}{l}\text { childhood } \\
\text { diseases }\end{array}$ & $\begin{array}{l}\text { respiratory tract } \\
\text { infections (often) }\end{array}$ & $\begin{array}{c}\text { chronic } \\
\text { tonsillitis } \\
\text { (till } 20 \text { years) }\end{array}$ & $\begin{array}{c}\text { cold-related } \\
\text { diseases (rare) }\end{array}$ & $\begin{array}{l}\text { acute rhinitis, } \\
\text { otitis, bronchitis, } \\
\text { tonsillitis; festering } \\
\text { conjunctivitis, } \\
\text { sharp sinusitis, } \\
\text { serous meningitis }\end{array}$ \\
\hline $\begin{array}{c}\text { family } \\
\text { medical history }\end{array}$ & $\begin{array}{l}\text { heart attack } \\
\text { (Grandmother), } \\
\text { Hashimoto's } \\
\text { thyroiditis } \\
\text { (Grandfather) }\end{array}$ & $\begin{array}{l}\text { depression } \\
\text { with suicidal } \\
\text { outcome } \\
\text { (father) }\end{array}$ & - & - \\
\hline Obesity & + & - & - & - \\
\hline
\end{tabular}




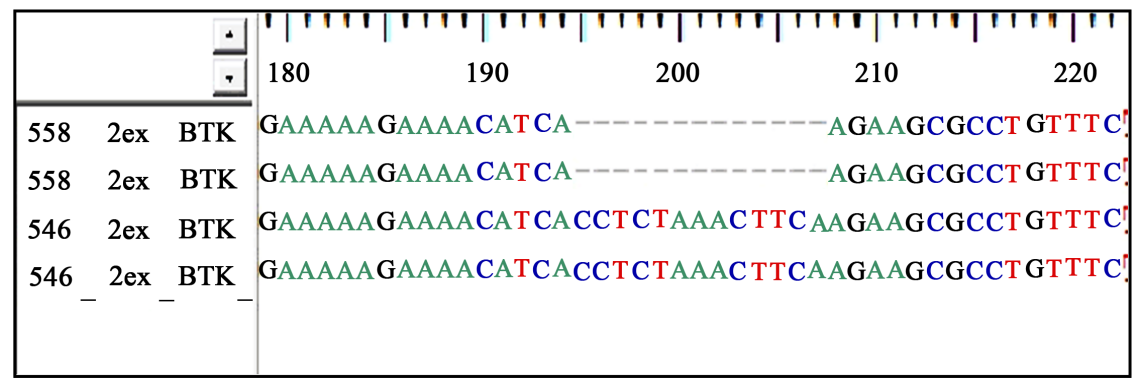

Figure 1. A fragment of sequencing genetic research of BTK-gene. Refers: 558 - the fragment of proband's DNA in exon 2 of gene $B T K$ (direct and reject strands of DNA) (hemyzygous c.64-76del13 marked by dotted line); 546-the same fragment of healthy donor.

In the first three months of life the baby was breast-fed and had no signs of illness. At the age of 3.5 month the first symptoms appeared as an acute respiratory viral infection with acute rhinitis, exsudative otitis, acute bronchitis. He was hospitalized, got antibiotic therapy and discharged with the improvement.

In 7 days after being discharged-the repeated hospitalization concerning a festering conjunctivitis, sharp sinusitis on a background sub fibrillated fevers. After fit therapy he was discharged from hospital in the satisfactory state.

At the age of 5.5 months he was undergone a repeated episode of high subfebrile condition up to $38^{\circ} \mathrm{C}$, acute tonsillitis with vesicular eruptions on the mucosa of the soft palate and palatine tonsils. The child was hospitalized again, when presented serous meningitis presumably of enterovirus etiology was revealed. After the introduction of the antibiotic, an urticaria rash and discharge spots appeared throughout the body and limbs. Symptomatic therapy with prednisolone with a positive effect was carried out. After two weeks he was discharged in a satisfactory condition.

Five days after the previous hospitalization at the age of 6 months, the child again had hoarseness and cough, and he was hospitalized again with a diagnosis of serous meningitis.

The clinical characteristics of immunocompromised patient are reflected in Table 3.

After improving the clinical state the immunophenotyping of lymphocytes was carried out. A lack of $\mathrm{CD}^{19+}$ lymphocytes were detected (Table 4).

The child received regular replacement therapy with intravenous immunoglobulin at a dose of $0.4 \mathrm{~g} / \mathrm{kg}$ in the saturation regimen to increase the Ig G level to $8.0 \mathrm{~g} / \mathrm{l}$. A clinical diagnosis of agammaglobulinemia was considered. To verify it a molecular genetic study was carried out.

After analyzing the genealogy no direct evidence of the presence of hereditary complications in primary immunodeficiency was revealed. From the hereditary data it is known that the mother under the age of 20 had annual exacerbations of chronic tonsillitis, the grandmother of the patient on the maternal line and both her sisters are healthy, and the grandfather on the maternal line in the third generation committed suicide at 29 years because of being depressed. 
Table 3. Clinical characteristics of boy during hospitalization at regional clinical children hospital No.1 in Yekaterinburg.

\begin{tabular}{cccc}
\hline & 08.12 .2016 & 10.12 .2016 & Reference range \\
\hline $\mathrm{Hb} \mathrm{g/l}$ & 109 & 114 & $110-140$ \\
$\mathrm{WBC} \times 10^{9} / \mathrm{L}$ & 34.7 & 27.4 & $5.5-12.5$ \\
Metamyelocytes\% & 0 & 2 & - \\
Stab\% & 13 & 21 & $0.5-4$ \\
Seg\% & 7 & 44 & $15-45$ \\
Lymph\% & 20 & 25 & $42-74$ \\
Mono\% & 60 & 6 & $2-12$ \\
Eosinophil\% & 0 & 1 & $0.5-7$ \\
Ig A g/l & 0.05 & 0 & $0.1-0.4 \mathrm{~g} / 1$ \\
Ig M g/l & 0.2 & 0.6 & $0.4-1.8 \mathrm{~g} / \mathrm{l}$ \\
Ig G g/l & 0.75 & $<0.7$ & $1.2-12.8 \mathrm{~g} / 1$ \\
\hline
\end{tabular}

Table 4. Laboratory analyses of patient at 6 months.

\begin{tabular}{|c|c|c|}
\hline & $\begin{array}{l}\text { Patient laboratory values } \\
\text { (total count of leucocytes } \mathrm{L}=7.15 \times 10^{9} / \mathrm{l} \text { ) }\end{array}$ & $\begin{array}{l}\text { Normal laboratory } \\
\quad \text { values [7] }\end{array}$ \\
\hline $\mathrm{CD}^{3+}$ lymphocytes & $\begin{array}{c}93 \% \\
\left(6.65 \times 10^{9} / 1\right)\end{array}$ & $\begin{array}{c}45 \%-79 \% \\
\left(2.28-6.45 \times 10^{9} / 1\right)\end{array}$ \\
\hline $\mathrm{CD}^{4+}$ lymphocytes & $\begin{array}{c}61 \% \\
\left(4.36 \times 10^{9} / 1\right)\end{array}$ & $\begin{array}{c}36 \%-61 \% \\
\left(1.69-4.60 \times 10^{9} / 1\right)\end{array}$ \\
\hline $\mathrm{CD}^{8+}$ lymphocytes & $\begin{array}{c}31 \% \\
\left(2.22 \times 10^{9} / 1\right)\end{array}$ & $\begin{array}{c}16 \%-34 \% \\
\left(0.72-2.45 \times 10^{9} / 1\right)\end{array}$ \\
\hline $\mathrm{CD}^{16+}$ lymphocytes & $\begin{array}{c}7 \% \\
\left(0.5 \times 10^{9} / 1\right)\end{array}$ & $\begin{array}{c}6.2 \%-18.2 \% \\
0.38-0.97 \times 10^{9} / 1\end{array}$ \\
\hline $\mathrm{CD}^{19+}$ lymphocytes & $\begin{array}{c}0 \% \\
\left(0.0 \times 10^{9} / 1\right)\end{array}$ & $\begin{array}{c}19 \%-31 \% \\
\left(0.3-1.5 \times 10^{9} / 1\right)\end{array}$ \\
\hline $\mathrm{CD}^{25+}$ lymphocytes & $\begin{array}{c}4.5 \% \\
\left(0.32 \times 10^{9} / 1\right)\end{array}$ & $0.32 \times 10^{9} / 1$ \\
\hline TNK & $\begin{array}{c}4.1 \% \\
\left(0.29 \times 10^{9} / 1\right)\end{array}$ & \\
\hline HLA-DR+ & $\begin{array}{c}22 \% \\
\left(1.57 \times 10^{9} / 1\right)\end{array}$ & \\
\hline $\operatorname{Ig} \mathrm{A}$ & $0.0 \mathrm{~g} / 1$ & $0.1-0.4 \mathrm{~g} / 1$ \\
\hline $\operatorname{Ig} \mathrm{M}$ & $0.6 \mathrm{~g} / 1$ & $0.4-1.8 \mathrm{~g} / \mathrm{l}$ \\
\hline Ig G & $<0.7 \mathrm{~g} / \mathrm{l}$ & $1.2-12.8 \mathrm{~g} / \mathrm{l}$ \\
\hline
\end{tabular}

The father of proband had recurrent infections of respiratory tract in childhood, at present hi is obese. Great-grandmother on paternal side died from a heart attack, great-grandfather suffered from autoimmune thyroiditis. There was no consanguineous marriage in this case. 


\section{Results}

Retrospective study of copy numbers of T-cell recombination excision circles (TREC) and kappa-deleting element recombination circle (KREC) was performed in dry blood spot for neonatal routine screening of 4-day old patient. It has shown total lack of KREC in genetic material upon normal copy number of TREC $\left(\right.$ KREC $=0$, TREC $=280$ copies per $10^{4}$ leucocytes; normal levels for KREC $>25$ copies per $10^{4}$ leucocytes, for TREC $>250$ copies per $10^{4}$ leucocytes [8]). It confirmed genetic reason of B-cell deficiency in that patient.

In order to verify diagnosis of agammaglobulinemia, sample from patient has undergone amplification of gDNA, covering coding sequence of BTK gene including splice site junctions within introns.

Deletion of $13 \mathrm{bp}$ in 2 exon was detected through Sanger sequencing of BTK gene: c.64_76del13 (delCCTCTAAACTTCA), p.P22fsTer28 (Figure 1).

This genetic variant is not described in various databases; however performed calculations demonstrated that the detected loss in genetic material has a pathogenic nature as it leads to a frameshift and occurence of premature stop-codon.

After genetic verification of X-linked agammaglobulinemia diagnosis in this boy, his family was offered a molecular-genetic testing for revealing the carrier status of this mutation in mother and sister of proband. Performed analysis confirmed presence of the above microdeletion in both female relatives (Appendix Figure 1).

The direct sequencing of 50 people of Russian origin from Sverdlovsk region was performed and the c.64_76del13 variant was not detected (data not shown).

Besides in future we plan to prove the pathogenicity of this mutation using analysis of expression of BTK in cell lines.

\section{Discussion}

It is well known that XLA is characterized by early onset of recurrent infections and prompt diagnostics still remain the principal challenge. In represented clinical case timely testing of newborn for KREC could prevent development of severe infections in boy in the first month of life and significantly reduce the period of correct diagnosis.

An infectious agent that led to the meningitis in this patient was not determined, but in terms of the results of the cerebrospinal fluid test, we can assume its viral nature. There are some data that indicate that meningitis in XLA can be evoked by echoviruses that can be combined with dermatological manifestations [9]. In this patient the symptoms of meningitis were accompanied by a skin rash, which was stopped by a single administration of corticosteroids that denies its infectious nature. It is also known that besides infectious symptoms in XLA, non-infectious complications such as idiopathic bowel diseases, seasonal allergies, aseptic arthritis, dermatomyositis-like syndrome, etc. are observed [10].

Obtained results don't enable to carry precise forecast of clinical course in all patients with such frameshift BTK mutation with emergence of premature 
stop-codon. Nevertheless, this study performs comprehensive description of the mutation and phenotype that may serve to database updating for further functional investigations.

\section{References}

[1] Toth, B., Volokha, A., Mihas, A., et al. (2009) Genetic and Demographic Features of X-Linked Agammaglobulinemia in Eastern and Central Europe: A Cohort Study. Molecular Immunology, 46, 2140-2146. https://doi.org/10.1016/j.molimm.2009.03.012

[2] López-Granados, E., Pérez de Diego, R., Ferreira Cerdán, A., et al. (2005) A Genotype-Phenotype Correlation Study in a Group of 54 Patients with X-Linked Agammaglobulinemia. Journal of Allergy and Clinical Immunology, 116, 690-697. https://doi.org/10.1016/j.jaci.2005.04.043

[3] Pamela, P., Lee, W., Chen, T.-X., Jiang, L.-P., et al. (2010) Clinical Characteristics and Genotype-Phenotype Correlation in 62 Patients with X-Linked Agammaglobulinemia. Journal of Clinical Immunology, 30, 121-131. https://doi.org/10.1007/s10875-009-9341-5

[4] Khaydukov, S., Baidun, L., Zurochka, A. and Totolyan, A. (2012) Methods. Medical Immunology (Russia), 14, 255-268. (In Russian) https://doi.org/10.15789/1563-0625-2012-3-255-268

[5] Gordukova, M.A., Oskorbin, I.P., Mishukova, O.V., et al. (2015) Development of Real-Time Multiplex PCR for the Quantitative Determination of TREC's and KREC's in Whole Blood and in Dried Blood Spots. Medical Immunology (Russia)/Meditsinskaya Immunologiya, 17, 467-478. https://doi.org/10.15789/1563-0625-2015-5-467-478

[6] Ogino, S., Gulley, M.L., den Dunnen, J.T., et al. (2007) Association for Molecular Pathology Training and Education Committee. Standard Mutation Nomenclature in Molecular Diagnostics: Practical and Educational Challenges. The Journal of Molecular Diagnostics: JMD, 9, 1-6. https://doi.org/10.2353/jmoldx.2007.060081

[7] Shcherbina, A.Y., Pashanov, Y.D. and Medpraktika-M, M. (2006) Childhood Immunology. A Practical Guide to Children's Illness. (In Russian.)

[8] Deryabina, S.S., Tuzankina, I.A., Vlasova, E.V., Bolkov, M.A. and Shershnev, V.N. (2017) Neonatal Screening for Severe Combined Immune Deficiency in Russia: Glorious Future or Tomorrow's Reality? Current Pediatrics, 16, 59-66. (In Russian) https://doi.org/10.15690/vsp.v16i1.1696

[9] Janeway, C.A., Gitlin, D., Craig, J.M. and Grice, D.C. (1956) “Collagen Disease” in Patients with Congenital Agammaglobulinemia. Trans Assoc Am Physicians, 69, 93-97.

[10] Behniafard, N., Aghamohammadi, A., Abolhassani, H., et al. (2012) Autoimmunity in X-Linked Agammaglobulinemia: Kawasaki Disease and Review of the Literature. Expert Review of Clinical Immunology, 8, 155-159. https://doi.org/10.1586/eci.11.94 
S. Deryabina et al.

Appendix
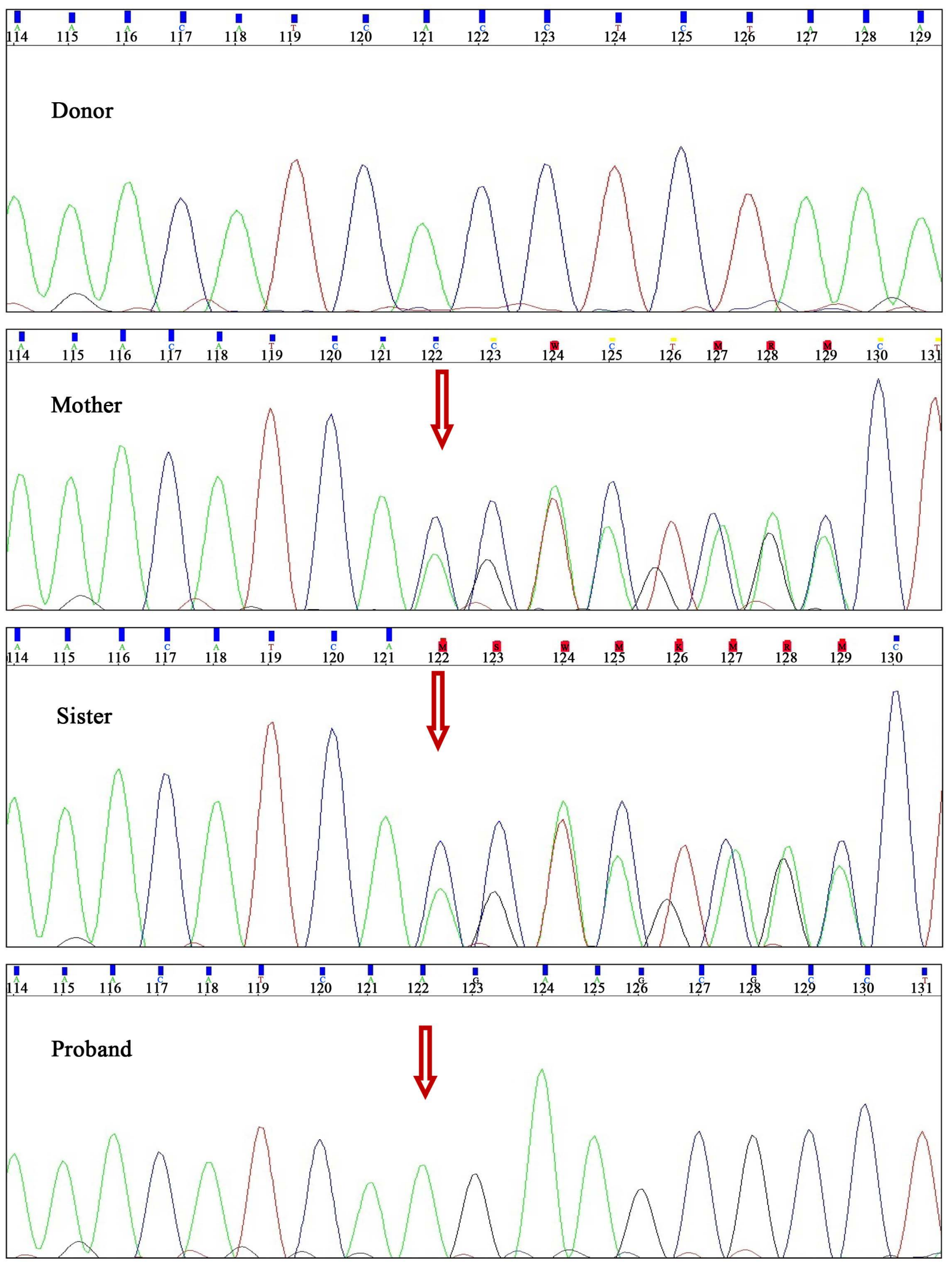

Figure 1. Chromatogram sequence of proband and family members. The start location of the deletion is indicated by the arrow.

DOl: $10.4236 / \mathrm{crcm} .2017 .610027$

249

Case Reports in Clinical Medicine 